\title{
Continuance intention of using e- book among higher education students
}

\author{
I. Tri-Agif, A. Noorhidawati and S. Ghazal Ghalebandi \\ Department of Library \& Information Science \\ Faculty of Computer Science \& Information Technology \\ University of Malaya, Kuala Lumpur, MALAYSIA \\ e-mail: agif@siswa.um.edu.my; noorhidawati@um.edu.my (corresponding author); \\ ghazal.ghalebandi@siswa.um.edu.my
}

\begin{abstract}
This paper investigates determinant of continuance intention to use e-book among higher education students. The determinants used in this paper are adopted from Technology Acceptance Model (TAM) and Expectancy Disconfirmation Theory (EDT). The quantitative study employed random sampling where the email invitation which contained a hypertext link of the survey page, enables the participants to access to the survey hosted in Google Drive. Out of 760 sample size, a total of 650 responses were gathered with 509 valid responses used for analysis. The data were analysed to test the relationship between determinants of continuance intention to use e-book among higher education students. The finding demonstrates that determinant of continuance intention to use ebook are based on Satisfaction, while Satisfaction is strongly determined by Perceived Ease of Use and Confirmation of using e-book. Internet self-efficacy is reported to have strong effect on Satisfaction through Perceived Ease of Use, while Perceived Quality affects Satisfaction of using ebook through Confirmation. In general findings from this study are beneficial for libraries in that determinants of continuance intention of using e-books could also be used in selecting and evaluating e-books features before subscription. Additionally e-book vendors could use these findings to improve and enhance features of their e-books services.
\end{abstract}

Keywords: E-book; Electronic books; Higher education; Academic libraries; Continuance intention.

\section{INTRODUCTION}

E-book has become a prominent service in libraries as it provides user with convenient means of accessing resources in the digital era. Nowadays, most of the libraries including academic libraries have included e-book in their collections. This has motivated researcher to further understand user acceptance and perception towards e-book for their reading or referring, as well as to examine usage pattern of e-books. The e-book service offered by the library is likely to have contented users in which the satisfaction could cause users' intention to continuously use it for various purposes. Previous research by Patterson and Spreng (1997) indicated that satisfaction has a positive effect on future intention, while Bhattarcherjee (2001) reported an essential link between satisfaction and continuance intention to use e-book. 
To date, there has been no study in the Library and Information Science (LIS) literature that was conducted to determine factors that support continuation intention to use e-book in academic library in a wider scope, particularly in relation to its usability, quality, satisfactory, subjective norms and control. Therefore this study is conducted to fill this gap in order to gather a better understanding on continuance intention to use e-book among students in higher education. This study is important to assist libraries in considering and planning inclusion and/or increase of e-books in their collection as Walters, (2013) also reported that only half of the print books acquired by academic libraries are available as ebooks.

\section{LITERATURE REVIEW}

\section{Perception and Intention of E-book Users}

E-book services in academic libraries have been in place for years and were being accepted by users. Nearly 90 percent of university libraries owned or subscribed to e-books in 2007, and more recent estimates range from 94 to 97 percent (Walters 2013). Several studies such as Borchert et al. (2009) and Noorhidawati and Gibb (2008) investigated awareness level of e-book collection. On the other hand, awareness in fact motivates people's intention to use, which eventually leads to e-book usage and preference among the user. For example, Oliveira (2012) investigated student's perceptions, behaviour and attitudes towards e-book in academic library. His finding reported that users preferred to use printed book rather than e-book although he indicated that e-book users were satisfied with the feature of e-book. In addition, Nicholas et al. (2008) reported 61.8 percent of their respondents use e-book for various purposes. Another report on a large-scale survey that was carried out to assess academic awareness, perceptions and usage levels of e-books in a university in UK, found significant number of reading media preference (Rowlands et al. 2007). The result indicated 48 percent of the respondents prefer to read e-book on screen, only 13 percent prefer to read on paper, while percent vary in using screen, paper or other media to read. This is probably because the choice of using either e-book or printed book depends on the availability of information needed by user. A very recent survey study in India on the other hand concluded that users are not significantly concerned by the choice of e-book or printed book, but on the availability of information source regardless of whether it is in digital or printed format (Ramaiah 2012).

In variation of e-book usage such as reading or referring, Ismail and Zainab (2005) reported that e-books were mainly used for supporting students' work in completing their research project and assignment. This result is supported by another study which pointed that ebooks were used for reference rather than for reading (Noorhidawati and Gibb 2008). This could possibly be due to the available features offered by e-book such as search tools that provides ease of use for referring task. This is supported by (Clark and Rumbold, 2006) who also reported students appreciated and valued the convenience of e-book features such as portability (non-physical), mobility (easy access) and searching features. Moreover, Foote and Rupp-Serrano (2010) found that students desired e-books feature particularly in relation to searching, highlighting, and taking notes which are common functions when using books as reference materials.

Richardson and Mahmood (2012) conducted a study to investigate user satisfaction when using different e-readers (iPad, Barnes and Noble's Noke, Border's Kobo Reader and Sony 
Digital Reader) for reading e-book. They found that portability, ease of use and collections provided are the most desirable features. Another study related to continuance use of ereader found that user intention to use is solely determined by attitude, which refers to the perception of content enrichment and device personalization (Chou, Stu, and Lin 2010). These two studies were conducted mainly to investigate factors that influence people to continue to use specific e-book reader, which in turn would help the practitioners, researcher or stakeholder in understanding what are the desirable design, method and features to generally satisfy the users.

\section{Research Models to Understand E-Book Usage}

Available research models have been reviewed systematically to examine elements that could develop valuable insight in understanding e-book users particularly related to continuance intention of using of e-book (Borchert et al. 2009; Letchumanan \& Tarmizi 2011; Tsai 2012).

Shin (2011) conducted a study examining e-book users' experience by integrating Uses and Gratifications Theory (UGT), Expectation Confirmation Theory (ECT) and Diffusion Theory (DT). UGT is used as a theoretical framework to understand specific reasons why users use a specific media, while ECT is a theory that suggests confirmation based on the pre and post behaviour that influences continuation intention and satisfaction as postulated originally by Oliver (1980). DT on the other hand, provides a systematic, demand-side explanation on how and when newly introduced technologies are communicated, adopted, evaluated, rejected, and re-evaluated by users (Rogers 1995). Shin (2011) in addition found that moderating effect of confirmation/gratification and demographic are significant as predecessor of e-book technology acceptance.

There are few recent studies focused on concepts such as perceived quality, subjective norms, satisfaction and their relationships on continuous intention use of e-books. The continuance intention to use a particular product is by the level of satisfaction to the product (Al-Maghrabi and Dennis 2011; Chen et al. 2009; Zhao and Cao 2012). The study by Roca et al. (2006) reported perceived quality has significant effect to the confirmation. They also indicated that interpersonal and external influence (subjective norm) had no significant impact on the satisfaction of using e-book; while perceived quality including system quality and information quality could become the determinants of e-book satisfaction by mean of confirmation on using e-book. On the other hand, Joint (2010) found that e-book has neither proven itself as a transformational technology in the context of library services, nor as a consumer product to be sold directly to end users. It does have the potential to be so, if certain problems related to usability, business models and library finding tools are addressed.

With the advent of technology and growth of online reading materials such as e-books as part of library services, a 2012 survey by the Pew Research Center (Zickuhr et al. 2012) found that while 12 percent of e-book users borrowed e-books from their public libraries, 58 per cent of library card holders and 48 per cent of dedicated e-book reader owners did not know if their libraries lent e-books. A recent study by (Martindale, Willett and Jones (2015) highlighted that the principal motivating factors for use of the library services are convenience and time-saving, as opposed to physical remoteness from a library or accessibility issues. They investigated the impact of the new e-lending scheme on the users of libraries operated by Derbyshire County Council and findings showed that this service 
was very highly valued, and its users would wish it to be continued and, if possible, extended and improved, most obviously by increasing the stock.

In accordance with technology implementation, the Technology Acceptance Model (TAM) is the most common model being used in understanding the acceptance of a technology being applied and accepted in a specific environment. In e-book research, TAM has been used in several studies. For example, Tsai (2012) conducted a study to understand user behaviour as a primary key in understanding the e-book market. The findings indicated brand, service, trust, and perceived usefulness to have a positive effect on the attitude towards using e-book, while attitudes towards using e-book has significant effect on the continuance intention to use. Other than TAM, there is also a reliable framework proposed by Roca, Chiu and Martinez (2006), investigating the continuance intention of using an elearning system. The framework consists of TAM as well as a combination model of Theory of Planned Behavior (TPB), TAM and Expectancy Disconfirmation Theory (EDT). Although a number of studies were conducted to evaluate e-book usage, there has been no study to date that specifically investigates continuance intention to use e-book in an academic library. Therefore a combination of continuance intention model (using TPB, TAM and EDT) as suggested by Roca, Chiu and Martínez (2006) is adopted in this study.

\section{OBJECTIVE AND METHOD}

The main objective of this study is to identify the factors that influence continuation use of e-book in higher education learning. The following research questions were addressed:

a) What are the factors that affect students' perception on e-book usability?

b) What are the factors that influence students' satisfaction in using e-books?

c) What are the factors that encourage confirmation of using e-book among students?

d) What are the factors that influence e-book continuance intention?

This study employed a quantitative research method, which included design of the research instrument for data collection (questionnaire) adapted from Roca, Chiu and Martínez's (2006), and data analysis. The questionnaire was divided into three sections: (a) respondent's demographic information, (b) e-book usage, and (c) perception on continuance intention in using e-book. For measuring respondents continuance intention in using e-book, this study used seven-point Likert-type measurement scale, decoded as $1=$ strongly disagree, 2 =disagree, $3=$ somewhat disagree, $4=$ =undecided, $5=$ somewhat agree, $6=$ agree and $7=$ strongly agree.

\section{Hypotheses and Research Model}

The study investigates the factors that influence continuance intention of using e-book among higher education students, adopting a research model proposed by Roca, Chiu and Martinez (2006). The model is based on the following three theoretical frameworks: TPB, TAM and EDT. The model includes six main constructs in investigating the continuance intention to use e-books, which are perceived quality, perceived usability, perceived control, subjective norms, confirmation and satisfaction as shown in Figure 1. For the purpose of this study, user satisfaction is a determinant of continuation intention in using e-book where the satisfaction's predictors are the perceived quality, perceived usability, 
confirmation and subjective norms. This study is conducted to provide evidence to the following hypotheses:

$\mathrm{H} 1$ : there is a statistically significant relationship between perceived quality and confirmation of using e-books.

$\mathrm{H} 2$ : there is a statistically significant relationship between perceived quality and satisfaction of using e-books.

H3: there is a statistically significant relationship between confirmation and perceived usability of using e-books.

$\mathrm{H} 4$ : there is a statistically significant relationship between confirmation and satisfaction in using e-books.

H5: there is a statistically significant relationship between subjective norms and satisfaction in using e-books.

H6: there is a statistically significant relationship between perceived control and perceived usability of using e-books.

H7: there is a statistically significant relationship between perceived usability and satisfaction in using e-books.

H8: there is a statistically significant relationship between satisfaction and continuance intention of using e-books.

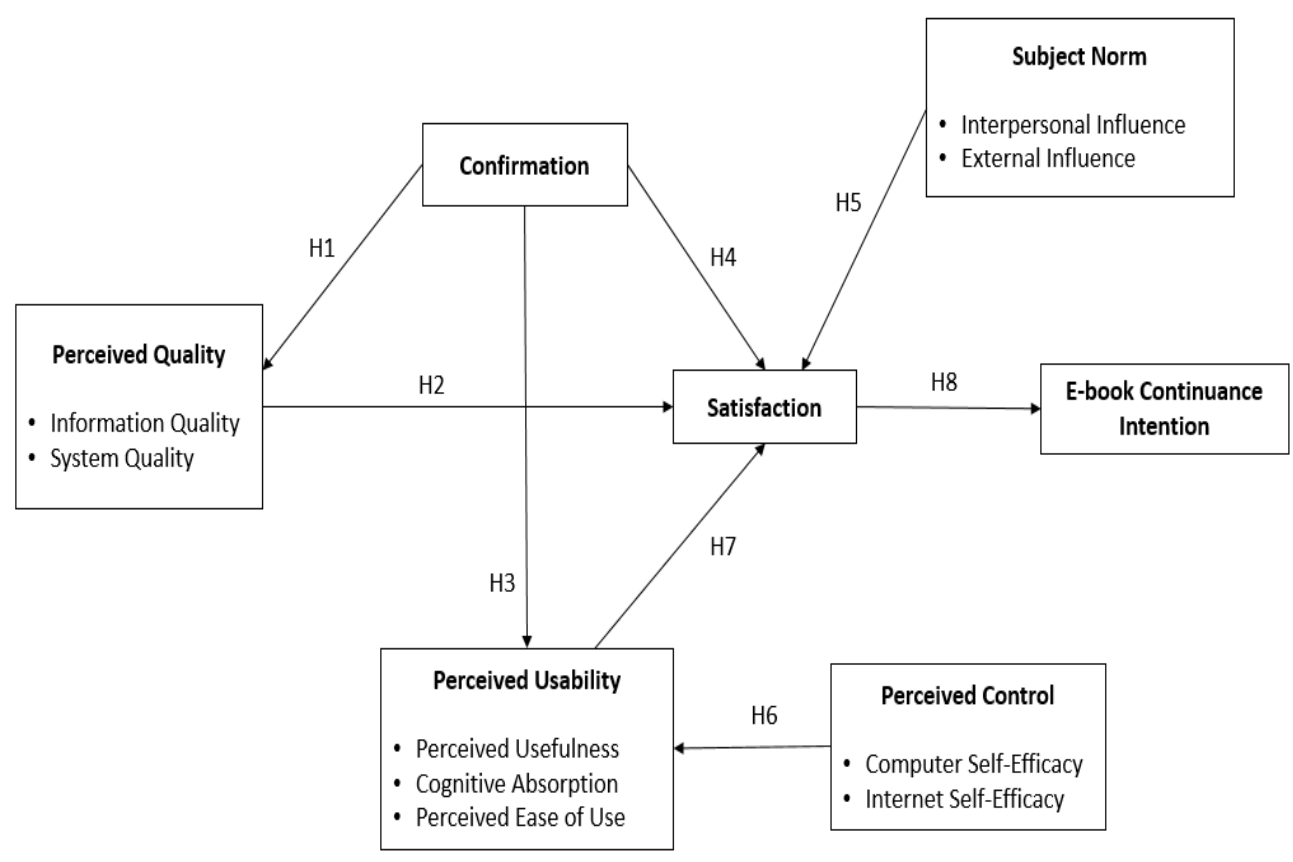

Figure 1: The Research Model for Continuance Intention to Use E-book 


\section{Data Collection}

The study employed random sampling technique where e-mail invitation to the survey link was distributed to respondents' email address. The e-mail addresses were obtained from the university's academic division. The sample size was determined based on Krejcie and Morgan (1970) population and sample table. With a population of 23,000 students (as reported by university registrar at the point of data collection), the sample size was determined as 760 (Confidence Level $=95 \%$, Margin of Error $=3.5 \%$ ). The e-mail invitation, which contained a hypertext link, enables the participants to link to the survey database hosted in Google Drive.

Table 1 shows the survey response rate. After two rounds of distributions, responses were received from 650 respondents out of which, 508 (78.15\%) were completed and used for analysis. The response rate is exceptionally good for online survey as Gravetter and Forzano (2008) indicated a typical response rate for online survey is only about 18 percent. This is probably due to the incentive given to the participants who would win a lucky draw after completing the survey. This was done using a random number generator in Microsoft Excel spreadsheet to generate numbers that were previously assigned to the e-mail addresses.

Table 1: Survey Response Rate

\begin{tabular}{l|r}
\hline \hline Total Population & 23,000 \\
\hline \hline Total sample & 760 \\
\hline \hline Clicked on survey link & 650 \\
\hline \hline Incomplete survey & 141 \\
\hline \hline Non-completion rate & $21.7 \%$ \\
\hline \hline Completed survey & 509 \\
\hline \hline Response rate & $78.3 \%$ \\
\hline \hline
\end{tabular}

\section{Data Analysis}

The scale items in the questionnaire were subjected to factor analysis test and reliability analysis. For the factor analysis to be considered appropriate, Bartlett's test of Sphericity should be significant at $p<.05$, and values of the Kaiser-Meyer-Olkin (KMO) measure of sampling adequacy should be between 0.6 and 1.0 as shown in Table 2. For this study, scale items that recorded factor loading of less than 0.4 were not accepted. The internal consistency of each scale was measured using Cronbach's alpha. Measures of reliability range from 0 to 1 , and each scale should exhibit adequate reliability with Cronbach's alpha close to or above the recommended 0.70 level as shown in Table 3. To answer the research questions, we applied the non-parametric tests Spearman's rho the multiple linear regression analysis. Table 4 shows the means and standard deviation values determined for the six constructs analysed in this paper. 
Table 2: Bartlett's Test and KMO Measure

\begin{tabular}{lccc}
\hline Constructs & KMO & $\begin{array}{c}\text { Bartlett's } \\
\text { test Sig }\end{array}$ & $\begin{array}{c}\text { Percentage of } \\
\text { Variance } \\
\text { explained }\end{array}$ \\
\hline Perceived Usefulness & .732 & .000 & 81.775 \\
Perceived Cognitive Absorption & .782 & .000 & 53.77 \\
Perceived Ease of Use & .723 & .000 & 79.26 \\
Perceived Internet Self-efficacy & .712 & .000 & 77.57 \\
Perceived Computer Self-efficacy & .770 & .000 & 63.17 \\
Interpersonal Influence & .663 & .000 & 79.65 \\
External influence & .717 & .000 & 78.09 \\
Information quality & .781 & .000 & 35.22 \\
System quality & .836 & .000 & 50.90 \\
Confirmation & .736 & .000 & 77.98 \\
Satisfaction & .761 & .000 & 85.59 \\
Continuance intention & .747 & .000 & 87.04 \\
\hline
\end{tabular}

Table 3: Cronbach's Alpha and Factor Loading

\begin{tabular}{l|c}
\hline \hline Perceived Usefulness: Cronbach's $\alpha=0.89$ & Loading \\
\hline \hline 1. Using e-book can improve my study performance & .923 \\
2. Using e-book can increase my study effectiveness & .915 \\
3. I find e-book is useful to me & .874 \\
\hline \hline Perceived Cognitive Absorption: Cronbach's $\alpha=0.81$ & Loading \\
\hline \hline 4. Time files when I am reading/referring e-book & .460 \\
5. Most times when I read e-book, I end up spending more time than I had & .722 \\
planned & .732 \\
6. When I am accessing e-book, I am able to block out most other distractions \\
7. While using e-book, I am absorbed in what I am doing & .811 \\
8. I have fun interacting with the e-book & .820 \\
9. I enjoy using the e-book & .792 \\
\hline \hline Perceived Ease of Use: Cronbach's $\alpha=0.87$ & Loading \\
\hline \hline 10. Learning to use e-book is easy for me & .866 \\
11. It is easy for me to become skillful at using the e-book system & .916 \\
12. My interaction with e-book system is clear and understandable & .888 \\
\hline \hline Perceived Internet Self-efficacy: Cronbach's $\alpha=0.85$ & Loading \\
\hline \hline 13. I feel confident in navigating the e-book by following hyperlinks \\
14. I feel confident in the e-book system searching information \\
15. I feel confident in the e-book system downloading e-book & .903 \\
\hline \hline Perceived Computer Self-efficacy: Cronbach's $\alpha=0.81$ & .900 \\
\hline \hline 16. I could complete my reading/referring activities using e-book if I had never \\
used any e-book system like it before & .837 \\
17. I could complete my reading/referring activities using e-book if I had only \\
the e-book system manuals for reference \\
18. I could complete my reading/referring activities using e-book if I had seen \\
someone else using it before trying it myself \\
19. I could complete my reading/referring activities using e-book if I had just \\
the built-in-help facility for assistance & .806 \\
\hline \hline
\end{tabular}




\begin{tabular}{|c|c|}
\hline Interpersonal Influence: Cronbach's $\alpha=0.87$ & Loading \\
\hline 20. My family thought I should use e-book & .818 \\
\hline 21. My colleagues thought I should use e-book & .943 \\
\hline 22. My friends thought I should use e-book & .911 \\
\hline External influence: Cronbach's $\alpha=0.85$ & Loading \\
\hline 23. I read/saw news reports that using e-book was a good way of reading & .870 \\
\hline 24. Expert opinions depicted a positive sentiment for using e-book & .913 \\
\hline 25. Mass media reports convinced me to use e-book & .868 \\
\hline Information quality: Cronbach's $\alpha=0.70$ & Loading \\
\hline 26. The e-book provides relevant information for my study & .704 \\
\hline 27. The e-book does not provide easy-to-understand information (R) & .745 \\
\hline 28. The output e-book from the e-book system is not clear (R) & - \\
\hline 29. The e-book system presents the e-book in an appropriate format & .623 \\
\hline 30. The information content in the e-book is very good & .773 \\
\hline 31. The e-book from the e-book system is up-to-date enough for my purposes & .747 \\
\hline $\begin{array}{l}\text { 32. The collection of e-book that the e-book system delivers is not sufficient } \\
\text { for my purposes (R) }\end{array}$ & - \\
\hline 33. The reliability of output information from e-book system is high & .723 \\
\hline 34. The e-book system provides the information I need in time & .745 \\
\hline System quality: Cronbach's $\alpha=0.72$ & Loading \\
\hline $\begin{array}{l}\text { 35. Number of steps to access an e-book in the e-book system are too many } \\
\text { 36. Steps to access \& navigate e-book in the e-book system follow a logic } \\
\text { sequence }\end{array}$ & - \\
\hline 37. Navigating e-book in the e-book system always leads to a predicted result & .813 \\
\hline 38. The organization of information on the e-book system screens is clear & .799 \\
\hline 39. The e-book system has natural and predictable screen changes & .813 \\
\hline 40. The e-book system responds quickly during the busiest hours of the day & .641 \\
\hline Confirmation: Cronbach's $\alpha=0.86$ & Loading \\
\hline 41. My experience with using the e-book was better than I expected & .888 \\
\hline 42. The services provided by e-book system was better than I expected & .881 \\
\hline $\begin{array}{l}\text { 43. Overall, most of my expectations from using the e-book system were } \\
\text { confirmed }\end{array}$ & .880 \\
\hline Satisfaction: Cronbach's $\alpha=0.92$ & Loading \\
\hline 44. I am satisfied with the performance of the e-book & .927 \\
\hline 45. I am pleased with the experience of using the e-book & .925 \\
\hline 46. My decision to use the e-book was a wise one & .923 \\
\hline Continuance Intention: Cronbach's $\alpha=0.92$ & Loading \\
\hline 47. I will use the e-book on a regular basis in the future & .948 \\
\hline 48. I will frequently use e-book in the future & .942 \\
\hline 49. I will strongly recommend others to use it & .908 \\
\hline
\end{tabular}

Notes:

- The item statements that didn't load are indicated as ( - ) and will not be used in the correlation and regression analysis

- (R) Reverse Item

- Scale: 1 = Strongly Disagree; 2 = Disagree; 3 = Somewhat Disagree; 4 = Undecided; 5 = Somewhat Agree; 6 = Agree; 7 = Strongly Agree 
Table 4: Descriptive Statistics of the Constructs

\begin{tabular}{lcc}
\hline \hline Constructs & Mean & SD \\
\hline Perceived Usefulness & 4.36 & 0.81 \\
Perceived Cognitive Absorption & 4.20 & 0.84 \\
Perceived Ease of Use & 4.34 & 0.81 \\
Perceived Internet Self-efficacy & 4.25 & 0.79 \\
Perceived Computer Self-efficacy & 4.05 & 0.95 \\
Interpersonal Influence & 3.48 & 0.99 \\
External Influence & 3.79 & 0.97 \\
Information Quality & 4.44 & 0.60 \\
System Quality & 4.23 & 0.67 \\
Confirmation & 4.04 & 0.78 \\
Satisfaction & 4.23 & 0.79 \\
Continuance Intention & 4.28 & 0.83 \\
\hline \hline
\end{tabular}

\section{FINDINGS AND DISCUSSION}

\section{Demographic Information}

Out of 509 total responses, 349 (68.6\%) were undergraduates while 160 (31.4\%) were postgraduate students. 253 respondents $(49.7 \%)$ were male and the other $256(50.3 \%)$ were female. Responses were gathered from 18 faculties in University of Malaya that include science and arts \& social science discipline. A high number of responses were obtained from three faculties which provided more than $49 \%$ of the overall response. Faculty of Science came top with 106 (20.8\%), Faculty of Engineering with 94 responses (18.5\%), and Faculty of Computer Science \& Information Technology with 51 (10.0\%). The number or respondents from each faculty is a reflection of its general population.

\section{E-books Usage}

In terms of e-book usage, $184(36.1 \%)$ respondents reported that they used e-book at least once a week; 117 (23.0\%) said that they read e-book at least once a month while only 95 (18.7\%) people used e-book on a daily basis; and 113 respondents $(22.2 \%)$ rarely read ebook. When comparing quantities of e-books read in the past 6 months, 305 (59.9\%) of the respondents read up to 10 e-books, 132 (25.9\%) read between 11 and 30 e-books, while the balance of $72(14.2 \%)$ of them were reading more than 30 e-books during the period.

When asked about how they got to know about e-book, 312 (61.3\%) of the respondents knew from the university library while 275 (54.0\%) respondents heard about it from their close family, friends and colleagues; 172 (33.8\%) of them knew of e-book from their lecturers; and 149 (29.3\%) of them only knew of e-book from the news and magazines (printed media). Another 81 (15.9\%) respondents provided other resources for example from online interactions, various websites and search engines.

For e-book category, 395 (77.6\%) respondents usually downloaded self-managed e-books from the Internet or other sources; 229 (45\%) of them downloaded from other providers such as Amazon, Google Books, iBook, Kobo and Scribd; 204 (40.1\%) of them read e-books from the e-book service subscribed by the university library. Regarding devices used to access e-books, 460 (90.4\%) respondents used computers and laptops; 187 (36.7\%) of 
them used smartphones to access while some 113 (22.2\%) also used tablets like iPad, Samsung Galaxy, and Playbook. Only 20 (3.9\%) respondents used dedicated e-book readers such as Amazon Kindle, Nook and Sony Reader.

\section{Addressing the Research Objectives}

\section{a) Factors that Influence Continuance Intention to Use E-book}

The findings validated all eight hypotheses with supported empirical data. Table 5 shows that there is a very strong statistically significant relationship between confirmation and satisfaction of using e-book ( $r h o=.750, p<.001$ ); satisfaction and continuance intention of using e-books ( $r h o=.743, p<.001$ ). Meanwhile, a strong statistically significant relationship was observed between perceived quality and confirmation of using e-books (rho $=.667$, $p<.001$ ); perceived quality and satisfaction of using e-books ( $r h o=.684, p<.001$ ); perceived usability and satisfaction in using e-books ( $r$ o $=.602, p<.001$ ). A moderate statistically significant relationship was observed between confirmation and perceived usability of using e-books ( $r$ ho $=.564, \mathrm{p}<.001$ ); perceived control and perceived usability of using ebooks (rho $=.501, p<.001$ ); subjective norms and satisfaction of using e-books (rho $=.495$, $\mathrm{p}<.001$ ). The result of the correlation analysis further indicate that the most significant contributor to continuance intention of using e-books is satisfaction (rho $=.743, p<.001$ ).

Perceived Usability appears to have strong statistical significant relationship with Satisfaction. This is consistent with findings of previous studies particularly by Agarwal and Karahanna (2000), Saade and Bahli (2005) and Zhang, Li and Sun (2006). It appears that Satisfaction is highly influenced by usability of e-book rather than by enjoyment in using and usefulness of e-book to the users. This seems to support the notion that a user-friendly e-book is relatively more important than other usability features of an e-book, which is inline with previous studies by Rai, Lang and Welker (2002) and Devaraj, Fan and Kohli (2002). Subjective Norms has moderate statistical correlation with Satisfaction. While Confirmation has the most significant correlation with Confirmation that corroborate with findings of several previous studies by Kanning and Bergmann (2009), Lin et al. (2005) and Yen and Lu (2008).

Table 5: Correlation Analysis between the Constructs

\begin{tabular}{lccccccc}
\hline \hline $\begin{array}{l}\text { Spearman's } \\
\text { rho }\end{array}$ & Confirmation & Satisfaction & $\begin{array}{c}\text { Continuance } \\
\text { Intention }\end{array}$ & $\begin{array}{c}\text { Perceived } \\
\text { Control }\end{array}$ & $\begin{array}{c}\text { Subjective } \\
\text { Norms }\end{array}$ & $\begin{array}{c}\text { Perceived } \\
\text { Usability }\end{array}$ & $\begin{array}{c}\text { Perceived } \\
\text { Quality }\end{array}$ \\
\hline Confirmation & 1.000 & $.750^{* *}$ & $.594^{* *}$ & $.451^{* *}$ & $.517^{* *}$ & $.564^{* *}$ & $.667^{* *}$ \\
$\begin{array}{l}\text { Satisfaction } \\
\text { Continuance }\end{array}$ & $.750^{* *}$ & 1.000 & $.743^{* *}$ & $.474^{* *}$ & $.495^{* *}$ & $.602^{* *}$ & $.684^{* *}$ \\
$\begin{array}{l}\text { Intention } \\
\text { Perceived }\end{array}$ & $.594^{* *}$ & $.743^{* *}$ & 1.000 & $.467^{* *}$ & $.493^{* *}$ & $.573^{* *}$ & $.590^{* *}$ \\
$\begin{array}{l}\text { Control } \\
\text { Subjective }\end{array}$ & $.451^{* *}$ & $.474^{* *}$ & $.467^{* *}$ & 1.000 & $.461^{* *}$ & $.501^{* *}$ & $.508^{* *}$ \\
$\begin{array}{l}\text { Norms } \\
\text { Perceived }\end{array}$ & $.517^{* *}$ & $.495^{* *}$ & $.493^{* *}$ & $.461^{* *}$ & 1.000 & $.533^{* *}$ & $.550^{* *}$ \\
$\begin{array}{l}\text { Usability } \\
\text { Perceived } \\
\text { Quality }\end{array}$ & $.564^{* *}$ & $.602^{* *}$ & $.573^{* *}$ & $.501^{* *}$ & $.533^{* *}$ & 1.000 & $.536^{* *}$ \\
\hline$*$. Correlation is significant at the 0.01 level (2-tailed) & $.667^{* *}$ & $.684^{* *}$ & $.590^{* *}$ & $.508^{* *}$ & $.550^{* *}$ & $.536^{* *}$ & 1.000 \\
\hline \hline
\end{tabular}


Satisfaction shows a very strong statistical significance relationship with Continuance Intention, thus affecting users' decisions on whether or not to continue with using e-books. Since Perceived Usability reported significant effect on Continuance Intention through Satisfaction, it is important for e-book developers to design and develop e-book systems that are user-friendly and less complicated to operate. Simple logical steps in e-book design would lead to a good perception on systems user-friendliness. For libraries, it is important to select e-book providers that employ easy-to-use systems. Confirmation, another antecedent of Satisfaction is influenced by Perceived Quality. Confirmation has a moderate statistical relationship with Perceived Usability of e-book which is consistent with a previous study by Lin, Wu and Tsai (2005). Perceived Quality appears to have a strong statistical relationship with Satisfaction of using e-books. This is in line with previous studies by McGill, Hobbs and Klobas (2003) and Bharati and Chaudhury (2004).

The research model was then tested using multiple standard regression analysis. The regression analysis (Table 6) shows 58.2 percent of the variance in e-book continual intention and the model reaches statistical significance (Sig. $=.000 ; p<.005$ ). Overall, when the variance explained by all other variables in the model is controlled for, the construct that makes the most significant unique contribution in explaining the dependent variable (e-book continuance intention) is Satisfaction (Beta $=0.508$, sig. $=0.00, p<.05$ ). Other variables that make significant contribution to explaining continuance intention are: Perceived Usability (Beta $=0.137$, sig $=0.001, p<.05$ ) and Subjective Norms (Beta $=0.107$, sig $=0.005, p<.05)$. Among the six predictors, the variables that is not making significant contribution to Continuous Intention is Confirmation (Beta $=0.027$, sig. $=0.586, p>.05$ ), Perceived Quality (Beta $=0.061$, sig. $=0.170, p>.05)$ and Perceived Control (Beta $=0.045$, sig. $=0.229, p>05$ )

Table 6: Result of Regression Analysis for the Research Model

\begin{tabular}{|c|c|c|c|}
\hline Model & $\begin{array}{c}\text { Unstandardized } \\
\text { Coefficients Beta } B\end{array}$ & Sig. & \multirow{8}{*}{$\begin{array}{l}\mathrm{R}^{2}=.582, \\
\text { Adjusted } \mathrm{R}^{2}=.577, \\
\mathrm{~F}=116.321, \\
\mathrm{p}<.01\end{array}$} \\
\hline 1 (Constant) & & .214 & \\
\hline Confirmation & .027 & .586 & \\
\hline Satisfaction & .508 & $.000 * *$ & \\
\hline Perceived Control & .045 & .229 & \\
\hline Subjective Norms & .107 & $.005 *$ & \\
\hline Perceived Usability & .137 & $.001 * *$ & \\
\hline Perceived Quality & .061 & .170 & \\
\hline
\end{tabular}

The final research model is shown in Figure 2 demonstrated that Satisfaction, Perceived Usability, and Subjective Norms significantly had influenced on Continuous Intention of using e-book. Although Confirmation, Perceived Quality, and Perceived Control are not statistically significant in the regression test, there are significant relationships between these factors with e-book Continuous Intention usage. In general, Continuance Intention to use e-book could be derived from user experience where satisfaction of e-book service influences user to continuously use e-book as their preference. Satisfaction has major 
impact in the intention of continual usage as reported by Zhao and Cao (2012). Therefore Continuance Intention to use e-book is driven by Satisfaction, Perceived Usability, and Subjective Norms that could be used to predict user decision to continuously use the ebooks.

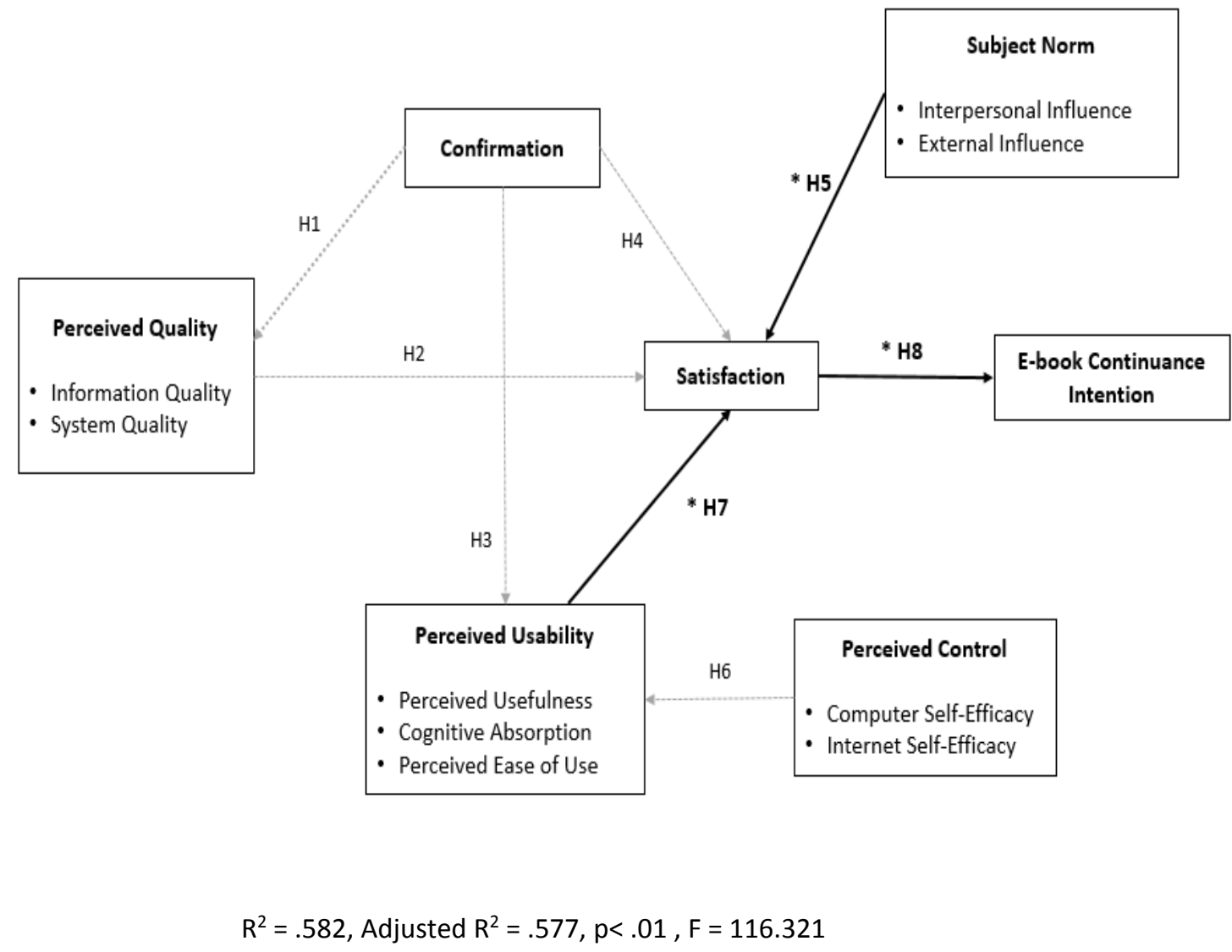

Figure 2: Final Research Model with Factors that significantly influenced Continuance Intention to Use E-book

\section{CONCLUSION}

This research identifies factors that affect continuance intention to use e-books among students in the higher education. The findings are useful to provide information to both library and e-book service providers to improve their services. In that for students to continually using e-book, it would be determined by several factors such as Satisfaction, Confirmation, Perceived Usability, Perceived Control and Perceived Quality. Although findings have supported the hypotheses, further investigations may be conducted to focus on a particular factor or on other specific group of user. This finding would be useful and beneficial for e-books implementation in higher education setting. Since the data gathered are adequate to demonstrate significance findings, these recommendations would hopefully bring some improvement in the services and on e-book provision in academic 
libraries. Having said that, this study does not refer to any specific e-book systems or services, as the respondents generally used several e-book types and systems or platforms. Therefore, this finding is only limited to the reflection of their experiences.

For further and stronger recommendation of the determinant for continuance intention to use e-book, more empirical works and replication of this research need to be carried out which focus on certain type of e-book system or service, as well as on different group of population. This could map and identify the antecedent of continuance intention to use a particular e-book system for certain group of user. It could also use the same research model for different system or technology implementation in information science research. This would enrich the knowledge and findings for different disciplines and could also provide different determinant pattern especially for continuance intention to use certain system or technology.

\section{ACKNOWLEDGEMENT}

This research received no specific grant from any funding agency in the public, commercial, or not-for-profit sectors.

\section{REFERENCES}

Agarwal, R. and Karahanna, E. 2000. Time flies when you're having fun: cognitive absorption and beliefs about information technology usage 1. MIS quarterly, Vol. 24, no. 4: 665-694.

Al-Maghrabi, T. and Dennis, C. 2011. What drives consumers' continuance intention to eshopping?: Conceptual framework and managerial implications in the case of Saudi Arabia. International Journal of Retail \& Distribution Management, Vol.39, no.12: 899926.

Bharati, P. and Chaudhury, A. 2004. An empirical investigation of decision-making satisfaction in web-based decision support systems. Decision support systems, Vol. 37, no. 2: 187-197.

Bhattacherjee, A. 2001. Understanding information systems continuance: an expectationconfirmation model. MIS quarterly, Vol. 25, no.3: 351-370.

Borchert, M., Hunter, A., Macdonald, D. and Tittel, C. 2009. Study on student and staff awareness, acceptance and usage of e-books at two Queensland universities. In 14th ALIA Information Online Conference \& Exhibition, 20-22 January 2009, Darling Harbour Exhibition and Convention Centre, Sydney. Available at: http://eprints.qut.edu.au/20379/.

Chen, S-C., Chen, H-H. and Chen, M-F. 2009. Determinants of satisfaction and continuance intention towards self-service technologies. Industrial Management \& Data Systems, Vol. 109, no. 9: 1248-1263.

Chou, S.C., Stu, J., and Lin, Y. 2010. Determinants of e-book readers adoption and continuation: A comparison of pre-adoption and post-adoption beliefs. In 5th International Computer Sciences and Convergence Information Technology (ICCIT), 30 Nov -2 Dec 2010, Seoul.

Clark, C. and Rumbold, K. 2006. Reading for pleasure: A research overview. Available at: http://pennykittle.net/uploads/images/PDFs/Reports/Reading_pleasure_2006.pdf. 
Devaraj, S., Fan, M. and Kohli, R. 2002. Antecedents of B2C channel satisfaction and preference: validating e-commerce metrics. Information Systems Research, Vol. 13, no. 3: 316-333.

Foote, J.B. and Rupp-Serrano, K. 2010. Exploring e-book usage among faculty and graduate students in the geosciences: results of a small survey and focus group approach. Science \& Technology Libraries, Vol. 29, no. 3: 216-234.

Gravetter, F. J. and Forzano, Lori-Ann B. 2008. Research methods for the behavioral sciences. Stamford: Gardners Books.

Ismail, R. and Zainab, A.N. 2005. The pattern of e-book use amongst undergraduates in Malaysia: A case of to know is to use. Malaysian Journal of Library \& Information Science, Vol. 10, no. 2: 1-23.

Joint, N. 2010. The electronic book: a transformational library technology? Library Review, Vol. 59, no. 2: 83-91.

Kanning, U.P. and Bergmann, N. 2009. Predictors of customer satisfaction: testing the classical paradigms. Managing Service Quality, Vol. 19, no.4: 377-390.

Krejcie, R.V. and Morgan, D.W. 1970. Determining sample size for research activities, Educational and Psychological Measurement, Vol. 30, 607-610.

Letchumanan, M. and Tarmizi, R.A. 2011. E-book utilization among mathematics students of Universiti Putra Malaysia (UPM). Library Hi Tech, Vol. 29, no.1:109-121.

Lin, C.S., Wu, S. and Tsai, R.J. 2005. Integrating perceived playfulness into expectationconfirmation model for web portal context. Information \& Management, Vol. 42, no. 5: 683-693.

Martindale, G., Willett, P., and Jones, R. 2015. Use and perceptions of e-books in Derbyshire libraries. Library Review, Vol. 64, no. 1/2: 2-20.

McGill, T., Hobbs, Va. And Klobas, J. 2003. User developed applications and information systems success: A test of DeLone and McLean's model. Information Resources Management Journal,Vol. 16, no. 1: 24-45.

Nicholas, D., Rowlands, I., Clark, D., Huntington, P., Jamali, H. R., and Ollé, C. 2008. UK scholarly e-book usage: A landmark survey. Aslib Proceedings: New Information Perspectives, Vol. 60, no. 4: 311-334.

Noorhidawati, A., and Gibb, F. 2008. How students use e-books - Reading or referring? Malaysian Journal of Library \& Information Science Vol. 13: 1-14.

Oliveira, S.M. 2012. E-textbooks usage by students at Andrews University: A study of attitudes, perceptions, and behaviors. Library Management, Vol. 33, no.8:536-560.

Oliver, R.L. 1980. A cognitive model of the antecedents and consequences of satisfaction decisions. Journal of Marketing Research: 460-469.

Patterson, P.G. and Spreng, R.A. 1997. Modelling the relationship between perceived value, satisfaction and repurchase intentions in a business-to-business, services context: an empirical examination. International Journal of Service Industry Management, Vol. 8, no. 5: 414-434. doi: 10.1108/09564239710189835.

Rai, A. Lang, S.S. and Welker, R.B. 2002. Assessing the validity of IS success models: An empirical test and theoretical analysis. Information Systems Research, Vol. 13, no. 1: 50-69.

Ramaiah, C.K. 2012. Users' perception about e-books in India. DESIDOC Journal of Library \& Information Technology, Vol. 32, no. 2: 86-94.

Richardson, J.V. and Mahmood, K. 2012. eBook readers: user satisfaction and usability issues. Library Hi Tech, Vol. 30, no. 1: 170-185. 
Roca, J.C, Chiu, C-M. and Martínez, F.J. 2006. Understanding e-learning continuance intention: An extension of the Technology Acceptance Model. International Journal of Human-Computer Studies, Vol. 64, no. 8: 683-696.

Rogers, E.M. 1995. Diffusion of Innovations: modifications of a model for telecommunications Die Diffusion von Innovationen in der Telekommunikation (pp. 2538): Springer.

Rowlands, I., Nicholas, D., Jamali, H.R. and Huntington, P. 2007. What do faculty and students really think about e-books? Aslib Proceedings, Vol. 59, no.6: 489-511.

Saadé, R. and Bahli, B. 2005. The impact of cognitive absorption on perceived usefulness and perceived ease of use in on-line learning: an extension of the technology acceptance model. Information \& Management, Vol. 42, no. 2: 317-327.

Shin, D-H. 2011. Understanding e-book users: Uses and gratification expectancy model. New Media \& Society, Vol. 13, no. 2: 260-278.

Tsai, W-C. 2012. A study of consumer behavioral intention to use e-books: the Technology Acceptance Model perspective. Innovative Marketing, Vol. 8, no. 4.

Walters, W. H. 2013. E-books in academic libraries: Challenges for Acquisition and collection management. Portal: Libraries and the Academy, Vol. 13, no. 2: 187-211.

Zickuhr, B. K., Rainie, L., Purcell, K., Madden, M., and Brenner, J. 2012. Libraries, patrons, and e-books. Available at: http://libraries.pewinternet.org/files/legacy-pdf/ PIP_Libraries_and_Ebook_Patrons 6.22.12.pdf

Yen, C-H. and Lu, H-P. 2008. Effects of e-service quality on loyalty intention: an empirical study in online auction. Managing Service Quality, Vol. 18, no. 2:127-146.

Zhang, P., Li, N. and Sun, H. 2006. Affective quality and cognitive absorption: Extending technology acceptance research. Paper presented at the System Sciences, 2006. HICSS'06 In Proceedings of the 39th Annual Hawaii International Conference, 4-7 Jan 2006, Hawaii.

Zhao, Z., and Cao, Q. 2012. An empirical study on continual usage intention of microblogging: the case of Sina. Nankai Business Review International, Vol. 3, no. 4:413-429. 